\title{
Evaluation of Shale Around Dange, Northwestern Nigeria as Raw Material for Drilling Mud
}

\author{
Oluwole. A. OYEDEJI ${ }^{1} \&$ Gabriel. O. Adeyemi ${ }^{2}$ \\ ${ }^{1}$ Nigerian Geological Survey Agency, Abuja, Nigeria \\ ${ }^{2}$ Geology Department, University of Ibadan, Ibadan, Nigeria \\ Correspondence: Oluwole A. Oyedeji, Nigerian Geological Survey Agency, P.M.B. 616, Abuja, Nigeria. E-mail: \\ geowol58@gmail.com
}

Received: June 18, 2018

Accepted: July 7, 2018

Online Published: January 26, 2019

doi:10.5539/esr.v8n1p19

URL: https://doi.org/10.5539/esr.v8n1p19

\begin{abstract}
Shale exposed around Dange northwestern, Nigeria was studied. The aim was to determine the grade, quality and usability of the shale as drilling mud using its physico-chemical and the rheological characteristics.

Sixty-one (61) samples were collected from exposed sections and pits. Major elements such as $\mathrm{SiO}_{2}, \mathrm{Al}_{2} \mathrm{O}_{3}, \mathrm{MgO}$ and $\mathrm{CaO}$ were determined. X-ray diffraction method was employed for the qualitative identification of the minerals in the shale. Cation Exchange Capacity and Exchangeable cations were determined using the Methylene Blue Absorption and Ammonium Acetate Saturation Methods respectively. Grain-size distribution and Atterberg Limits tests were also conducted. Apparent Viscosity, Plastic Viscosity and Yield point were calculated from readings obtained on a multi-speed Fann viscometer.

The dominant clay mineral observed is smectite (71\%) implying good expansive potential. Dominant oxides were $\mathrm{SiO}_{2}$ (42.60-57.50\%), $\mathrm{Al}_{2} \mathrm{O}_{3}(12.00-16.70 \%), \mathrm{CaO}(0.43-12.50 \%)$. Exchangeable cations obtained were $\mathrm{Na}^{+}(0.48-$ 6.67), $\mathrm{Ca}^{2+}(14.03-34.50)$ and $\mathrm{K}^{+}(0.42-1.95) \mathrm{meq} / 100 \mathrm{~g}$ clay. Liquid and plastic limits ranged from $69.40-86.00 \%$ and $30.10-36.10 \%$ respectively giving a Plasticity Index of $39.40-52.60 \%$.

The samples plot close to Ca-montmorillonite on the clay identification chart. The viscosity increased on addition of $7-10 \%$ sodium carbonate. It has good sodium exchange potential. In the natural state, it does not meet the API/OCMA specifications. However, its rheological properties improved significantly on treatment with sodium carbonate thus confirming its suitability as raw material in drilling mud.
\end{abstract}

Keywords: shale, cation exchange capacity, exchangeable cations, plastic viscosity, yield point

\section{Introduction}

The characteristics of subsurface formations encountered during drilling for oil and gas and water often dictate the need to use a drilling fluid. A drilling fluid may be water-based or air-based. The functions of a drilling mud include: transportation of rock cuttings to the surface, lubrication of the bit, application of hydrostatic pressure in the well bore, ensuring well safety and minimising fluid loss across permeable formations by forming a filter cake on the walls of the well. (Gray and Darley, 1980).

Common drilling fluids include potable water; water with additives either of clay, polymers and compressed air. Bentonite is used widely as constituents of water-based drilling mud in drilling operations.

Water-based drilling mud build a filter cake or rind on the borehole wall. This exerts a positive hydrostatic pressure against the borehole wall. It also helps to maintain borehole stability which helps to prevent invasion of the fluid into the borehole wall and reduce cross-contamination between aquifers.

Previous work on drilling mud in Nigeria had focused on the assessment of the suitability of the Nigerian black cotton soils in Northeastern Nigeria as drilling mud. (Omole et al, (1989), Eyisi et al, (1986), Oyedeji et al, (2006)). The purpose of this paper is to examine the suitability of the shale around Dange, northwestern Nigeria as raw material for drilling mud.

\subsection{Location}

The study area lies within latitude $12^{\circ} 50^{\prime} 00^{\prime}, \mathrm{N} 13^{\circ} 00^{\prime} 00^{\prime \prime} \mathrm{N}$ and longitude E. $5^{\circ} 15^{\prime} 00^{\prime \prime} \mathrm{E}$ and $5^{\circ} 25^{\prime} 00^{\prime \prime} \mathrm{E}$ 
covering a total area of $117 \mathrm{~km}^{2}$ within the southern portion of the Iullemeden Basin in northwestern Nigeria (Figure 1)

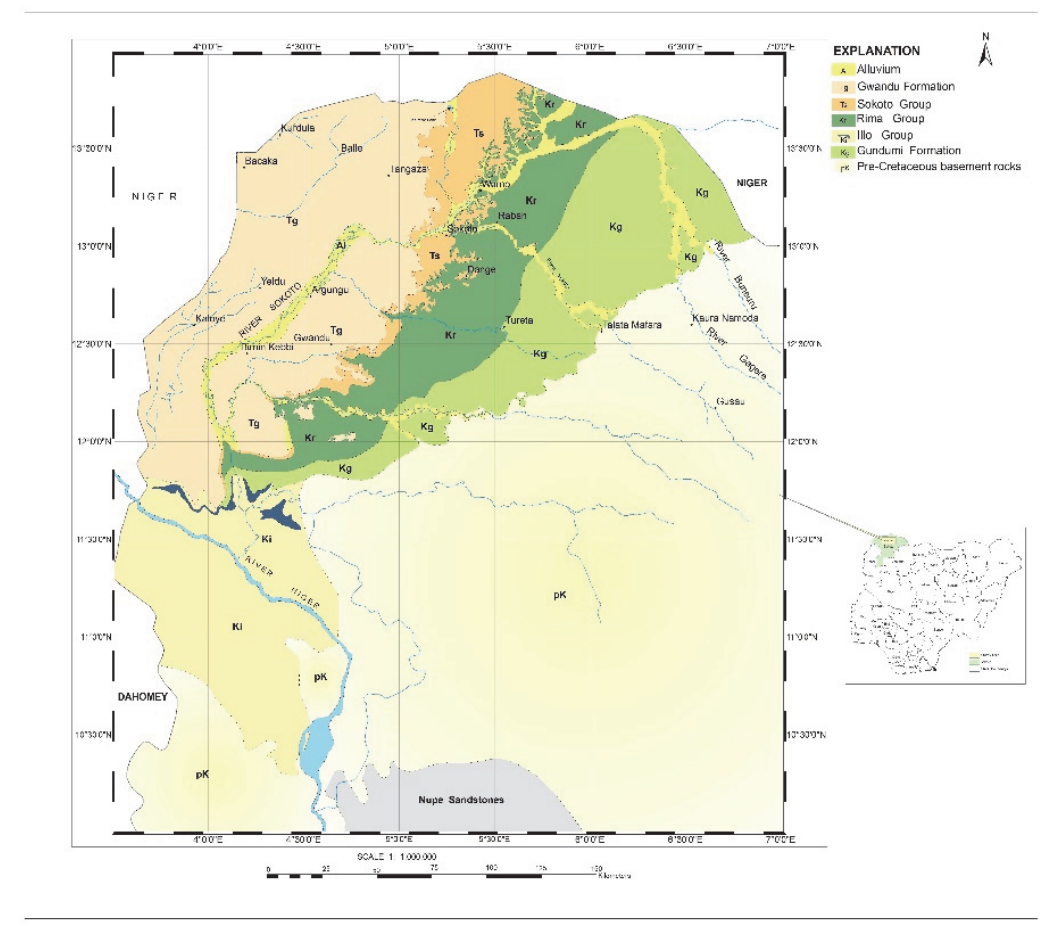

Figure 1. Map of Nigeria showing the location of study area

\section{Geology of the Study Area}

The shale around Dange consists of slightly indurated bluish-grey shale interbedded with thin layers of yellowishbrown limestone. The maximum thickness of the Formation is about $22 \mathrm{~m}$ in surface outcrops near Sokoto but in subsurface wells, it attains a thickness of over $45 \mathrm{~m}$. Generally, outcrops of the Formation are restricted to the slopes of the Dange Scarp. The shale includes bands of fibrous gypsum with numerous irregular phosphatic nodules. The nodules are characteristically marked with irregular striations and have an off-white external colour, but are bluish-grey internally (Obaje, 2009).

The type section of the Dange Formation is at Dange village (about $28 \mathrm{~km}$ south of Sokoto). The Dange Formation has a conformable contact with the underlying Kalambaina Formation. Geological Survey borehole no 3512 drilled at Dange village reveals the thickness of the Formation to be over $23 \mathrm{~m}$, South of Birnin Kebbi. At the quarry site of the cement factory at Kalambaina, fresh samples of the shale were observed below the limestone. Kogbe, (1986) identified, abundant and rich assemblage of calcareous benthic and agglutinated foraminifera in the Dange shale. Overlying the Dange shale is the Kalambaina Formation which is made up of light-grey-white nodular crystalline limestone, which is fossiliferous and about $1 \mathrm{~m}$ thick.

The Gwandu Formation is exposed as brownish-reddish highly consolidated Ironstones/laterites which cap the sections as overburden, with an average thickness of $1 \mathrm{~m}$.

\section{Materials and Methods}

\subsection{Fieldwork}

Geological mapping was carried out on a scale of 1: 50,000. Areas where the shales outcropped were delineated. Pitting was carried out at exposed outcrops. Sixty-one (61) Samples were collected from exposed sections, road cuts and stream channels in addition to the pits. (Figure 2). 


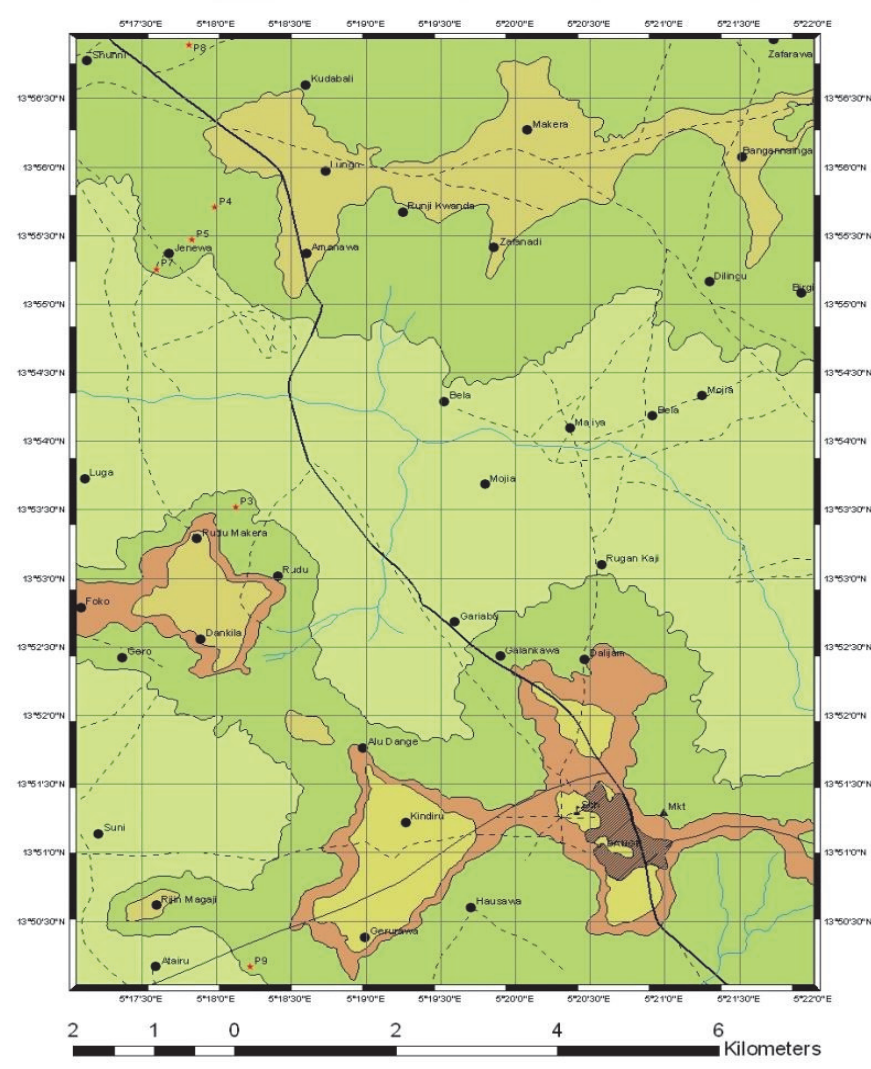

\section{Legend}

Gwss Gwandu Formation

Kls Kalambaina Formation

Dsh Dange Formation

$\mathrm{Kr}$ Rima Group

Sampling points

Builtup

Main Road

- - Minor Road

River

- Settlement

School

Market<smiles>FC1NC2(F)NC1S2</smiles>

Figure 2. Geological Map of the study area

\subsection{Laboratory Analyses}

Major elements were determined as oxides using the Inductively-coupled Mass spectrometry (ICP-MS) method. Cation Exchange Capacity (CEC) and Exchangeable cations were determined using the Methylene Blue Absorption (MBA) method. Surface area was determined using the Ammonium Acetate Saturation method (AMAS). The mineral types and the quantities were determined using X-ray Diffraction method, $\mathrm{pH}$ was also determined. Grain size distribution and Atterberg limits tests were also conducted. Rheological properties in terms of Apparent Viscosity (AV) and Yield Point were calculated from readings obtained on a multi-speed Fann viscometer.

\section{Results and Discussions}

The X-ray Diffraction results showed that the shale is made up of $67-86 \%$ clay and $6.60-21.26 \%$ quartz and Calcite $0.20-11.51 \%$. The clay content consists of $71 \%$ Smectite, Palygorskite $8 \%$, Illite/Mica $8 \%$, Kaolinite $11 \%$ and Chlorite $2 \%$, dickite, as clay minerals. All the samples showed the presence of smectite. Palygorskite is a magnesium-rich clay mineral. Magnesium affects the plasticity of clays and invariably the swelling potential of the clay. Some of the smectites identified were montmorillonite and nontronite in samples collected around Dange and Zafarawa. High smectite content is an indication of moderate to high swelling tendency, though this is dependent on the type of smectite, whether Na-smectites or Ca-smectites (Inglethorpe et al, 1993) (Figs 3 and 4). 


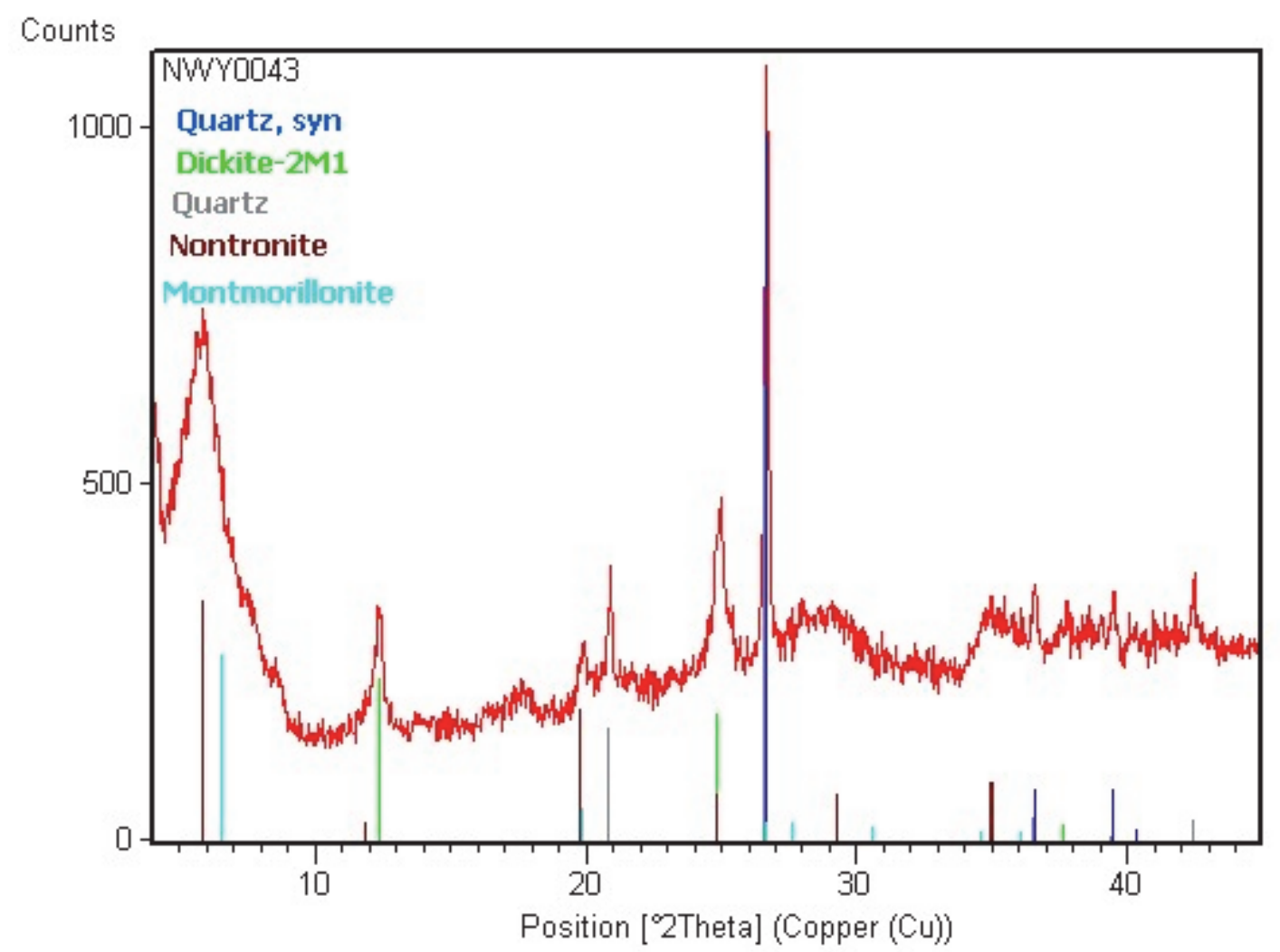

Figure 3. X-ray diffractogram for one of the shale samples 


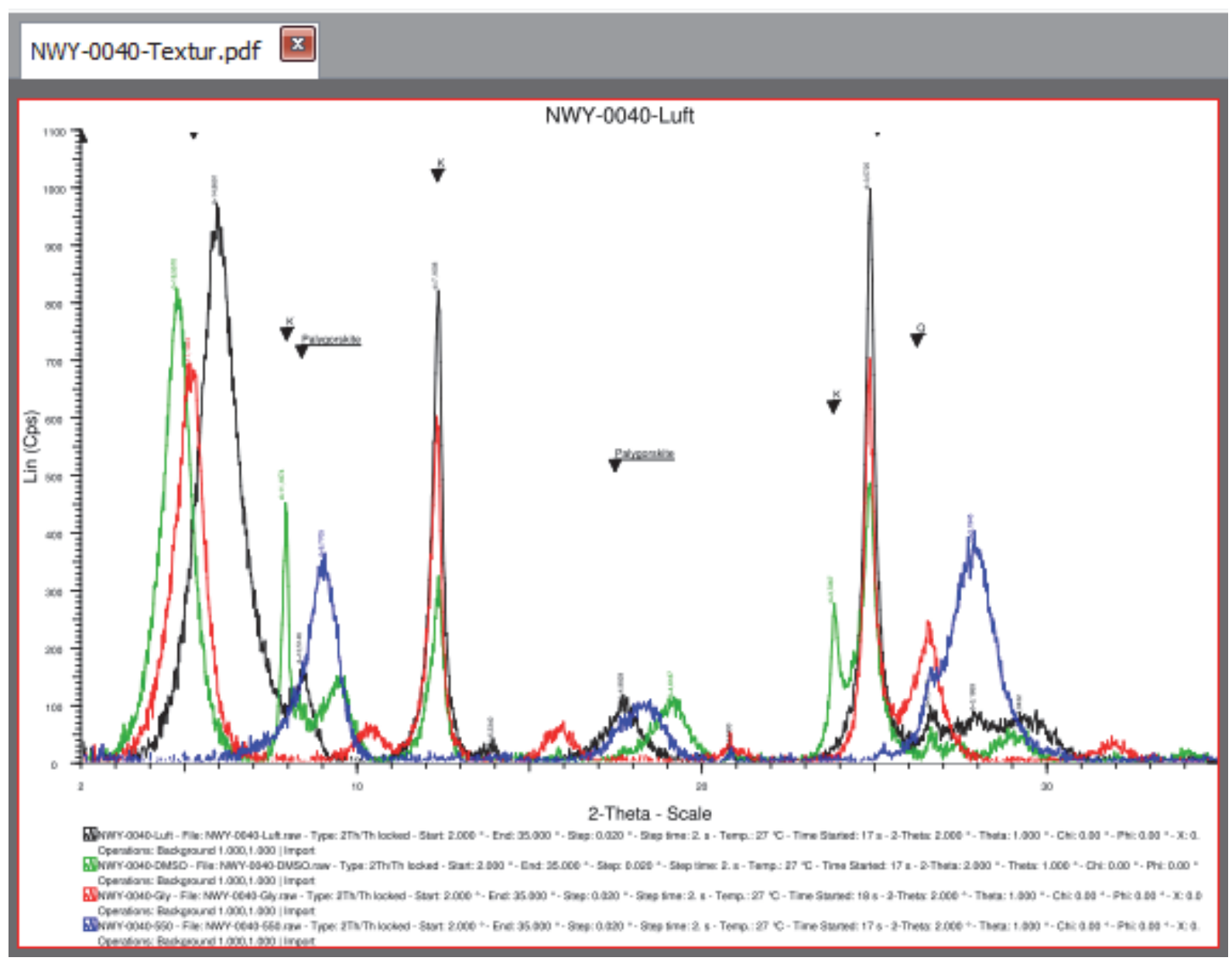

Figure 4. X-ray diffraction for a glycolated sample

The presence of palygorskite agrees with Dahab and Al- Blehed's (1992) observation on Saudi shales. The bulk mineralogy of the samples is dominated by clay minerals. Other minerals observed were quartz and calcite. The results of the major elements determined as oxides were $\mathrm{SiO} 2(42.60-57.50 \%), \mathrm{Al} 2 \mathrm{O} 3(12.0-16.7 \%)$ and $\mathrm{CaO}$ (0.43-12.50\%), Na2O (0.04-0.07\%), MgO (1.21-2.22\%), Fe2O3 (4.96-6.47\%), K2O (0.46-1.11\%) Cr2O3 (0.01$0.02 \%), \mathrm{TiO} 2$ (0.90-1.57\%), $\mathrm{MnO}(0.02-0.08 \%), \mathrm{P} 2 \mathrm{O} 5$ (0.35-2.23\%), $\mathrm{SrO}(0.02-0.03 \%)$ and $\mathrm{BaO}(0.01-0.02 \%)$. Loss on Ignition (LOI) varies from $16.2-24.3 \%$. SiO2 increased below $1.00 \mathrm{~m}$ and decreased between $2.00 \mathrm{~m}-3.00 \mathrm{~m}$. $\mathrm{A} 12 \mathrm{O} 3$ showed an increase below $1.00 \mathrm{~m}$ but stabilised between $2.00 \mathrm{~m}$ and $3.00 \mathrm{~m} \mathrm{CaO}$ is high towards the top because of the proximity to the Kalambaina formation which is made up of limestone. Al:Si ratio is between 1:3 and 1:4 which is close to the expected ratio in smectites. This is similar to the value 1:4.35 of obtained for Ubakala clays, Southeastern Nigeria by Apugo-Nwosu et al, 2011. This value is also indicative of low quantity of free quartz. The loss on ignition values are high implying high water of crystallinity. The values are also similar to the values obtained for the Ummer rad humma shales of Saudi Arabia.

Table 1. Major oxides compared with results from other countries

\begin{tabular}{lllllll}
\hline Oxides & $\begin{array}{l}\text { Wyoming } \\
\text { Bentonite }\end{array}$ & $\begin{array}{l}\text { California } \\
\text { montmorillonite }\end{array}$ & $\begin{array}{l}\text { Ein } \\
\text { Bayda } \\
\text { (Jordan) }\end{array}$ & $\begin{array}{l}\text { Al } \\
\text { Arabian }\end{array}$ & $\begin{array}{l}\text { Nigerian } \\
\text { bentonite } \\
\text { (after } \\
\text { Emofurieta, }\end{array}$ & Dange \\
& & & & & $2010)$ & \\
\hline $\mathrm{SiO}_{2}$ & 49.37 & 52.40 & 51.59 & $45.27-48.80$ & $42.60-57.50$ & $\begin{array}{l}47.24- \\
\end{array}$ \\
$\mathrm{Al}_{2} \mathrm{O}_{3}$ & 18.82 & 15.00 & 16.70 & $9.64-13.10$ & $12.00-16.70$ & $\begin{array}{l}53.06 \\
15.09-\end{array}$ \\
& & & & & & 20.97
\end{tabular}




\begin{tabular}{ccccccc}
$\mathrm{Fe}_{2} \mathrm{O}_{3}$ & 3.72 & 1.76 & 9.19 & $3.64-4.58$ & $4.96-6.47$ & $\begin{array}{l}4.71- \\
5.73\end{array}$ \\
$\mathrm{CaO}$ & 6.41 & 0.81 & 0.46 & $0.60-6.00$ & $0.93-12.50$ & $\begin{array}{l}3.43- \\
4.23\end{array}$ \\
$\mathrm{MgO}$ & 8.50 & 6.68 & 4.30 & $1.98-10.21$ & $1.22-2.22$ & $\begin{array}{l}3.49- \\
9.48\end{array}$ \\
& & & & & & \\
$\mathrm{Na}_{2} \mathrm{O}$ & 0.11 & 1.21 & 2.46 & Traces-1.63 & $0.04-0.06$ & $\begin{array}{l}\text { n.d.- } \\
\text { o.52 }\end{array}$ \\
\hline
\end{tabular}

The dominance of Calcium over Sodium agreees with Omole et al (1989), Dewu et al (2011), on Fika shale, northeast Nigeria, Osadebe et al (2011) on Imo shale from Okada, Southwestern Nigeria. pH obtained for the shale samples ranged from 7.46 to 8.46. Cation Exchange Capacity of the shale ranged between (32.08- $53.05 \mathrm{meq} / 100 \mathrm{~g}$ ) This value is low when compared with samples from Bulgaria (87.50), Turkey (77.50) but can be slightly ranked with samples from Jordan, (52.50) and Iraq (50.0). The standard Wyoming bentonite has values ranging between 80 and $120 \mathrm{meq} / 100 \mathrm{~g}$.

Many of the samples have fine fractions greater than $50 \%$. This portion include silt and clay-sized particles. \% fines ranged between $69.4 \%$ and $98.8 \%$. The high fines portion which is also referred to as colloids play the main role in clays that will be useful as drilling mud. This portion has a large specific surface which promotes the development of attraction forces and pushing away between separate particles. The colloids also develop strong negative charges on the edges. The interaction between these opposite charges at low speeds of flow strongly influences the viscosity of drilling muds. It is the reason for the formation of convertible structure when the mud rests (Kudaikulova et al, 2005). Sand-sized content ranged between 0.6 and 3.4\%. The low sand content will aid swellabilty and also enhance the viscosity of the mud and have minimum effect on the speed of drilling for the selection of the shale as drilling mud. This value also implies low abrasivity and wearing effect on the drilling equipment. The surface area values for the shale samples ranged between $183.40-299.109 \mathrm{~m}^{2} / \mathrm{g}$ ).

The liquid limit is an indicator of the bonding property of a swelling clay and is also one of the fundamental properties for various applications. It is also a sensitive indicator of the response of a $\mathrm{Ca}-\mathrm{Mg}$ bentonite to sodium exchange. The values obtained for the Liquid limit fall within the range of 64.3 and 110.6 . These values which are close to the lower limit value of $100 \%$ expected for Ca bentonite (100-200\%) are low. Many of the samples plot above the A-line and cluster within a narrow band between the $\mathrm{C}$ and $\mathrm{M}-\mathrm{O}$ soils showing that the samples have similar geologic origin. The clastic particles which form the shale might have been from the settlement of volcanic ash or other fine grained sedimentary materials.

The values of Liquid limit which are greater than $50 \%$ in all the samples imply that they can exhibit high compressibility. They can be classified as $\mathrm{CH}$ and $\mathrm{MH}$ which are fine-grained, silty Clays with medium to high plasticity. On the Bain's plasticity chart. The samples plot around the Ca-montmorillonite and Plastic kaolin. An increase in Liquid limit will translate into high CEC and a corresponding increase in swelling capacity.

Plastic Viscosity (PV) for raw samples ranged from $0.60 \mathrm{cp}-3.00 \mathrm{cp}$ while Yield Point (YP) ranged between $0.60 \mathrm{cp}-$ $6.50 \mathrm{cp}$. on addition of $7 \%-10 \%$ by weight of Sodium carbonate, $\mathrm{PV}$ increased from $0.60-6.50 \mathrm{cp}$ while YP increased from $0.50-33.00 \mathrm{cp}$. These results showed that the viscosity of the materials is generally low and does not meet the API standard which stipulates that Yield Point should be three times the Plastic Viscocity (Fig.5). 


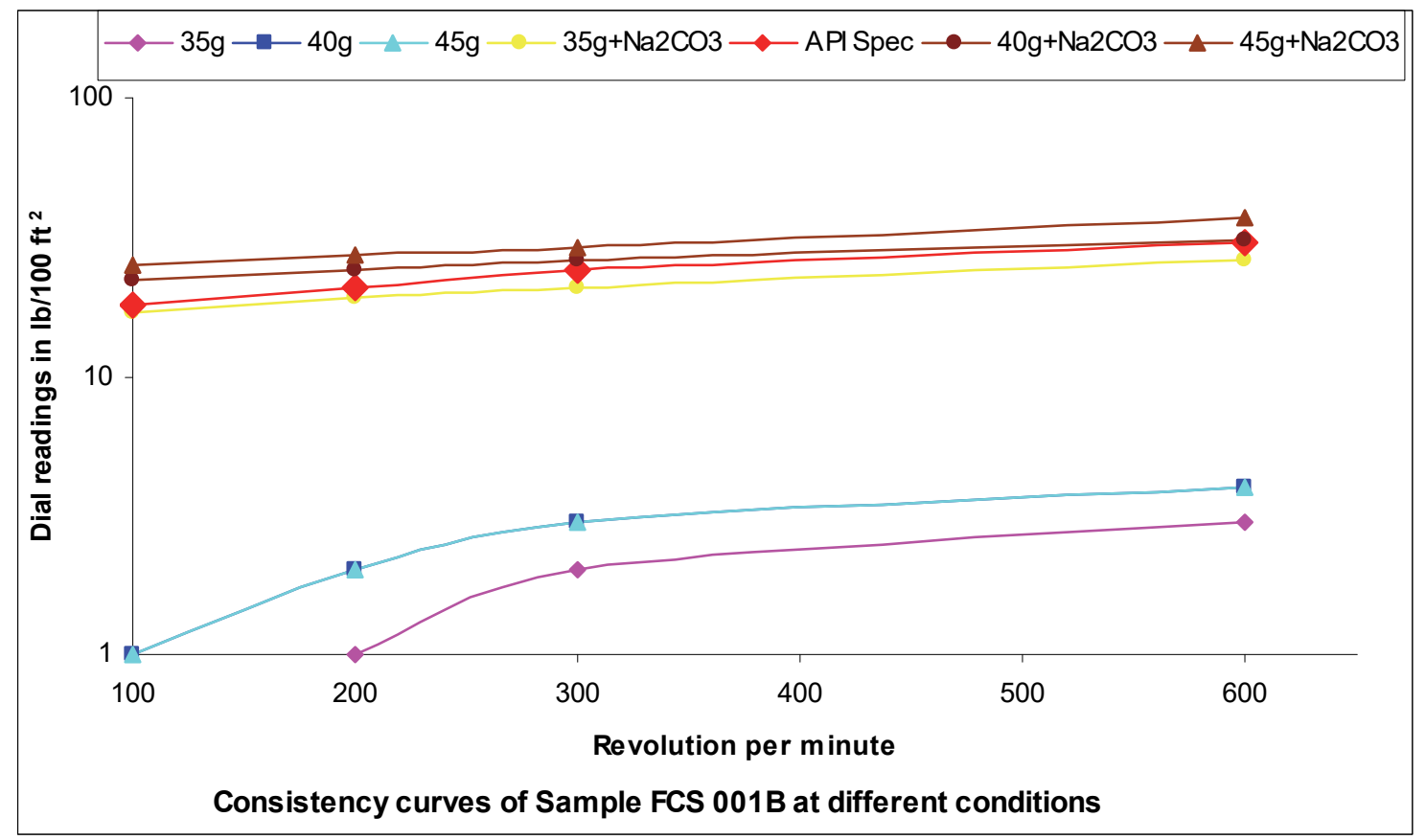

Figure 5. Consistency Curve for one of the shale samples

Though low viscosity enhances rotation of the drilling pipe, it is not adequate for hole cleaning and cutting and lifting purposes. Drilling mud that will lift cutting efficiently should have a high structural viscosity component. According to Darcy's law, fluid loss is inversely proportional to the viscosity. The results obtained were compared with the American Petroleum Institute (API) and Oil Companies Materials Association (OCMA). Increasing the mass of the materials and treatment with $7-10 \%$ by weight $\mathrm{Na} 2 \mathrm{CO} 3$ led to an increase in the viscosity of the materials

\section{Conclusion}

The samples are rich in Calcium and have good Sodium exchange potential. They also have low sand-sized particles content. The viscosity increased on addition of $7-10 \%$ sodium carbonate. In the natural state, it does not meet the API/OCMA specifications. However, its rheological properties improved significantly on treatment with sodium carbonate thus confirming its suitability as raw material in drilling mud.

\section{References}

Apugo-Nwosu, T. U., Mohammed-Dabo, I. A., Ahmed, A. S., Abubakar, G., Alkali, A. S., \& Ayilara, S. I. (2011). Studies on the suitability of Ubakala bentonitic clay for oil-well drilling mud formulation. Britishjournal of Applied science and technology, 1(4), 152-171.

Dahab, A. S., \& Al-Blehed M. S. (1991). Testing of Saudi shales for potential use in drilling fluids. J. King Saudi Univ.,4. Eng. Sc., (2), 221-227.

Darley, H. C. H., \& Gray, G. R. (1991). Composition and properties of drilling and completion fluids (5th ed.). Gulf Publishing Co., Houston, Texas, U.S.A. 643.

Eyisi A. E. O., Akemokwe, M. M., Abu L. O. I., \& Ngala, A. A. (1996). Bentonitic Clay Deposits in Ngala/Dikwa Areas Borno State, Nigeria. Unpublished NGSA rpt. 6.

Inglethorpe, S. D. J., Morgan, D. J., Highley, D. E., \& Bloodworth, A. J. (1993). Bentonite -Industrial Minerals laboratory Manual. BGS Tech Rpt WG/93/20. Mineralogy and Petrology Series, 116.

Kogbe, C. A. (1976). Microbiostratigraphy of lower Tertiary sediments from the southeastern flank of the Iullemeden basin. In N.W. Nigeria, \& Kogbe, C. E. (eds.), Geology of Nigeria, Elizabethan Publ Co., Lagos, Nigeria.

Kudaikulova, A. G., Strauss, H., \& Koeckritz, V. (2005). The Kazakhztan Clay for drilling muds. Acta Godynamica Geomaterialla, 2(2), 87-93. 
Obaje, N. G. (2009). Geology and mineral resources of Nigeria. Springer Publishers, 221.

Omole, O., Malomo, S., \& Akande S. (1989). The suitability of Nigeria Black Soil Clays as Drilling mud Clays. J. Applied Clay Science, 4, 357-372.

Osadebe, C. C., Obrike, S. E., \& Sulymon, N. A. (2011). Evaluation of Imo clay-shale deposit (Palaeocene) from Okada, Edo state, southwestern Nigeria as drilling mud clay. Journal of Applied technology in environmental sanitation, 1(4), 311-318.

Oyedeji, O. A., Ezeribe, I. Omole O., Okogbue C. O., \& Malomo, S. (2006). Research on the suitability of the Nigerian bentonite and black cotton soils as drilling mud 1 NW and NE Flanks. Unpublished NGSA report 355 .

\section{Copyrights}

Copyright for this article is retained by the author(s), with first publication rights granted to the journal.

This is an open-access article distributed under the terms and conditions of the Creative Commons Attribution license (http://creativecommons.org/licenses/by/4.0/). 